\title{
Learning Organization Models
}

\author{
Muh Said M.M \\ Suradi Tahmir \\ Juanda Nawawi \\ Universitas Negeri Makassar, South Sulawesi, Indonesia, Jln. Bonto Langkasa, Kamp. Gunung Sari Baru \\ Postal Code 90222; muh.said61@yahoo.com, radita_unm@yahoo.com, juandanawawi192@yahoo.co.id
}

\section{Doi:10.5901/mjss.2016.v7n2s1p172}

\begin{abstract}
Learning Organization is a concept where the organization is considered to give continuous learning independently, and the organization has a speed of thinking and acting in responding any change. Thus, the organization can create supporting atmosphere and give a wide opportunity to individuals to learn in groups and individually, and to apply the result of learning into the process and activities of the organization. According to Senge, there are five things that must be mastered namely, personal mastery, mental models, building shared vision, team learning, and systems thinking). These five basics were developed to establish the scope of the Learning Organization towards a learning in organization.
\end{abstract}

Keywords: Personal Mastery, Systems Thinking, Building Shared Vision, Learning Team, Mental Models

\section{Introduction}

In an increasingly competitive business world, change is a certainty. A company must be able to adapt to the challenges that exist to survive and give the best results. It can only be done if an organization becomes a learning organization. It occurs when an organization that is continually learning, receive new input, and utilize that knowledge into value-added. One of the important things in creating a Learning Organization is to create a culture of learning in a corporate environment; the employees are responsible and continue to develop themselves with the process of learning. Not only that, also the occurrence of a process of sharing knowledge between employees with each other.

In order to answer the problems and challenges of competitive business recently, we need a strategy of learning organization in management to solve the performance problems of the company. The concept of a learning organization is required to implement organizational learning to develop individual and organizational capabilities, and also to change the paradigm of "person - job fit" to "person - organization job". In this case, including the role and the responsibility of the leader to support successful learning organization, and the learning organization is expected to create a conducive environment for the management and the organization as a whole.

Senge (1990) issued a book "The Fifth Discipline Learning Organization and The Fifth Discipline Field book: Strategies and Tools for Building a Learning Organization," this book described the five disciplines that must be mastered when introduced into a learning organization, namely Personal Mastery, Systems Thinking, Building Shared Vision, Team Learning and Mental Models.

There are at least four things from the fifth discipline that addressed by Senge. First, an organization that implements a Learning Organization always supplies the organization with new ideas and information. Those come from science and technology, the surrounding environment, human resources development and other relevant sources. Secondly, learning which is acquired by the Organization or science about new ideas and information should be transferred to all elements of the organization both from the lowest level to the top level. Third, organizational behavior should be changed as a result of new science, and fourth, all elements in learning organization must have the courage to accept the changes and should not be afraid eliminated because the new changes to the organization. It is important to have a mindset that only senior management can and do all the thoughts for the entire company so that the company can be developed in appropriate era. Learning organizations challenged all employees to take advantage of the changes and their potential, with the hope that they can build their own community based on the principles of freedom, humanity, and a collective desire to learn.

In order to create learning organization in an organization, effective leadership is needed and not based on the 
traditional hierarchy, but rather, is a mix of different people from all levels of the system, which leads in a different way. Senge also said that in order to create the Learning Organization, there must be awareness that all people have the power to seek a solution to every problem that is faced by the individual, and that we will visualize the future and move forward to create it. Culture of the organization is based on openness and trust where each people supported and appreciated to learn and innovate, and thus can be promoted to the welfare of all employees. Creating a culture and environment that will act as a basis for learning organization begins with "mind shift - from seeing ourselves as separate from the world to connect to the world" (Senge, 2006: 37); it is needed to see ourselves as an integral component in the workplace, not as a separated wheel and unimportant part in the wheel. One of the biggest challenges that must be overcome in any organization is to identify the reasons and details of the way people defend themselves. Finally, there is no any change but a temporary phase (Argyris, 2008: 06). Everyone should learn that the measures they use to define and solve problems can be a source of additional problems for the organization (Argyris, 2008: 100).

Judging from the development of the Learning Organization management, the learning organization is conceptually contributed to the management. Starting in the 1980s introduced Total Quality Management that emphasizes the quality of ongoing improvement, then the 1990s are Reengineering and Benchmarking for improvement of business management strategy. In the 1990s, the organization of learning was introduced in the management to look for innovative ways to face the change and win the business competition. Organizational learning is very useful to help managers in the decision-making process of management, in particular, to take decisions that are not programmed with the creative. In this case, the learning organization encouraging managers continue to seek to improve the ability of both individual and group, to think and act creatively and optimize potential through learning. With the onset of the learning process means that managers motivate and help employees to take decisions and continuously to improve the effectiveness of the organization.

\subsection{Definition of Learning Organization}

Senge in translation (2006: 21) defines Learning Organization in Indonesian means Learning Organization where the individuals in it constantly increase their capacity to produce something they want. In an organization, there should be new thinking patterns and widely studied, the aspirations of the group were released and also learning how to learn together. However, this definition is not the only sense. There are still many other definitions depending on how the organizations adapt to the concept of Learning Organization. Other definition of learning organization of Senge defines learning organization as a discipline to develop the potential capability of individuals in the organization known as "The Fifth Discipline" as follows:

1) Personal skills are everyone in the organization has the understanding and the deeply personal views, and the opportunity to actualize the potential for individual and organizational success

2) Mental models namely how to act with the concept of frameworks that can facilitate the process of making a decision.

3) A shared vision is a common desire with determination and commitment to bringing every direction and motion of the entire organization together.

4) Learning team is a process of learning together in synergy team that starts with dialogue and continued with learning and empowering each other.

5) Systems thinking is a systematic and whole framework of individual and organizations lifestyles to think and act so that the organization can learn efficiently and productively.

Lately, some experts as quoted by Beardwell and Holden (2001) gave a broader definition of the learning organization, the organization that facilitates the learning of all its members and consciously transform the organizational context. The purpose and intended use of the learning process both individual, group and organizational, is to transform the organization to meet stakeholder satisfaction.

Pedlar, Boydell and Burgoyne (2005: 33) formulated the Learning Organization as "An organization that facilitates the learning of all its members and continuously transforms itself." Ortenblad (2002: 5) formulated Learning Organization as "Organization where individuals learn as agents for the organization and the knowledge is stored in the memory organization". Mayo and Lank (2005: 4) also formulated Learning Organization as "a learning organization harnesses the full brain power, knowledge and experience available to it, in order to evolve continually for the benefit of all its stakeholders".

But according to the author, Learning Organization is an organization that can create a learning atmosphere that provides the widest possible opportunity for every individual in the organization to learn individually and in groups then implies the study results into the process and activities of the organization. So, this learning activity does not stop on the 
system and mechanisms to learn, but on how to apply it, so it can be useful to the organization. Learning source itself can be from anywhere, both from internal and external.

\subsection{Scope of Learning Organization}

The scope of the Learning Organization includes the continuous and sustainable development, and also adjustments to the demolition of existing changes in the organization and be able to create goals and/or new approaches. This learning should be embedded in the way organizations carry out their activities. Learning in this case means:

1) That learning in an organizational transformation of knowledge in it is part of their daily work activities.

2) Application of Learning Organization is applied to the individual or, in the work unit of a company or overall organization.

3) Learning Organization as a whole will be able to solve the problem at the root and solve the problem as a whole.

4) The spread of knowledge throughout the organization structure can be beneficial where each person in the organization has the same knowledge so that they also have the same skill

5) Driven by the opportunity to acquire a significant change and do better.

Thus, the scope of Learning Organization covers a lot of things, especially in individuals within the organization, for example, employees in the company, including educational institutions in the form of employee training success is highly dependent on obtaining the opportunity to learn and practice new things and skills. Companies invest in education, training and a variety of other opportunities that are given to employees to grow and develop. The opportunity could be job rotation, salary increases to employees who excel and/or trained. On-the-job training is an effective way to train and draw a line better relationship between the interests and priorities of the company. Education and training programs can be conducted on advanced technologies such as computer-based training on the airways and the Internet and via satellite. Thus, learning is not only improving the quality of products and services produced by the organization. But also, an increase in work environments more responsive to the situation, adaptive, innovative and efficient, which in turn will improve performance and further strengthen the position of the organization.

\subsection{The Meaning of Reinforcement in Learning Organization}

Learning Organization requires the application of the approach, and one approach in the application of Learning using Reinforcement, because Reinforcement darting through a large role in education. Praise as part of the reinforcement given to the leader of the employees will always remember when administered in following the Learning. The compliment applies to all ages, not just the bottom of the employees are happy to be praised, but the leader of men, women and so happy to be praised. It's just a habit in leaders, praise it's still expensive. For instance, if the employee answered correctly, droop once the leader to give a greeting "good" or other expressions raised thumb. Praise is one part of reinforcement. For more details, we need to know the sense Reinforcement;

Reinforcement is a reinforcement that gives a positive response to a specific behavior of employees who allow such behavior comes back (Alma, Toyibin, 2010). The purpose of the reinforcement is able to increase the attention of employees, facilitate the learning process, generate and maintain motivation, change attitudes and lead to disruptive behavior productive learning, develop and organize themselves, lead to new ways of good thinking. Based on the description above, it can be concluded that reinforcement is empowerment that gives a positive response to a specific behavior of employees who allow such behavior recur.

\subsection{Reinforcement components}

The components of reinforcement skills or strengthening on the employees are important to be used by leaders to motivate employees to learn more. There are three components of reinforcement, namely:

\subsubsection{Verbal reinforcement}

Verbal reinforcement in the form of comments expressions compliments the form of words or sentences.

1) Words: good, great, terrific once, right once, very thorough and so on.

2) Sentences:

a) It is a good idea 
b) How critical thinking at all.

c) Thank you very clever.

\subsubsection{Gestural reinforcement}

Gestural reinforcement in the form of reinforcement showed through the face or other body members.

1) Face: smile, raised eyebrows, laughing, whistling, cast in the eye.

2) Members of the bodies: clapping, pointing, sign 0. k., raise your hands, nod, shake head (surprise), thumbs up, shrugged.

a. Proximity reinforcement: Proximity reinforcement as walked over, stood near, sitting close to the group, stands out among the employees.

b. Contact reinforcement: Pat the shoulders, back, hands on head, handshake, holding the hair, raised his hand. It should be noted the habit of the local area. There is a taboo holding the cheek, holding the head and so on.

c. Activity reinforcement: Walk ahead, share materials, lead a game, help using the tool, and listen to the music, radio, TV.

d. Token reinforcement: Gift, star comments are written in the workbook, honor, stamps, currency, image, ice, candles and the others.

Some principles of the use of reinforcement (Alma, Toyibin 2010), among others:

1) Full of warmth, enthusiasm and honest.

2) Avoid negative reinforcement: criticism and punishment.

3) Varies.

4) Full of meaning for students.

5) As a private.

6) Direct or immediate.

Based on the above it can be concluded that the reinforcement forms include verbal reinforcement, reinforcement and proximity gestural reinforcement, contact reinforcement, reinforcement activity, and a token reinforcement. Strengthening the provision of essential reinforcement or used by the leadership to further motivate employees to learn.

\subsection{Why companies need a learning organization}

Learning organizations conceptually have great benefits in the management process. In the 1980s has introduced Total Quality Management that emphasizes the quality of ongoing improvement, while the 1990s popularized Reengineering and Benchmarking for the improvement of business management strategy. In the 1990s also contributed to the organization of learning for management to look for innovative ways to deal with change and win the business competition.

In a market-based economic development (market-based economy) where the competition to win the market is very tight, we cannot rely on the comparative advantage with the mass and cheap labor. Instead we began to focus on the competitive advantage with educated workforce (well educated), trained (well trained) and control of information (well informed). A rapidly changing environment is actually a learning organization supports individuals and organizations to adapt to environmental changes. With the easy flow of information into the fabric of people's lives as a result of increasingly sophisticated information technology, then the employee is required is that people who have knowledge (knowledge people). Therefore, knowledgeable employees who work in a company should be considered as a major asset.

The company is in dire need of knowledge as an intangible asset whose value continues to grow. Thus, the company has a knowledge base that is optimal not only serve as a business organization that is profit but also as a learning organization that fosters all members of the organization. The company should consider the efforts of the development of human resources as a strategic option to improve competitiveness, and not just as expenditure.

In terms of management decision making, then organizational learning will help executives and managers to be able to make decisions, especially decisions not programmed more creative. Organizational learning is seen as an attempt to maximize the ability of managers to think and behave effectively and maximize its potential. That is, the manager can motivate and empower employees to make decisions independently.

In order to transform knowledge to all employees in the context of the learning organization, competence, and effective leadership are needed. The new competencies will equip employees to improve constantly their knowledge. In 
addition, the leadership has the support paradigm that empowers (empowerment), will give positive support to each member organization in learning activities.

The concept of a learning organization that has raised the experts mentioned above is ideal (das sollen), but the concept of organizational learning is still far from reality and less "grounded". In reality (das sein) there has been no framework and concrete measures to improve the effectiveness and efficiency of management, such as how the company has managed to become aware of learning organizations, whether executives and managers clearly understand the function and role in running a learning organization?

Research conducted Chase (1997) and Mayo (1998) showed that the obstacles that companies face in implementing a knowledge-based organization located in the corporate culture and the limitations of the use of information technology to support learning organizations. Even Lahteenmaki (1999) expressed some criticism of the concept of a learning organization, namely:

1. There is no clarification and multiplicity of definitions

2. There is no detailed explanation of the implementation of a learning organization system

3. There is no explanation how the system integrates organizational learning

Implementation of learning organization got failure caused by several reasons, according to research Lahteenmaki include:

1. Less consideration of uncertainty feelings and anxiety of employees to face of competition and changes

2. Less trust in workplace

3. Less feedback, motivation, discussion, and empowerment

4. Less attention to give responsibility for all employees to learn

5. There is no relation between organizational learning and human resource management strategy.

\section{Theoretical Framework}

The conceptual framework in this research as follow:

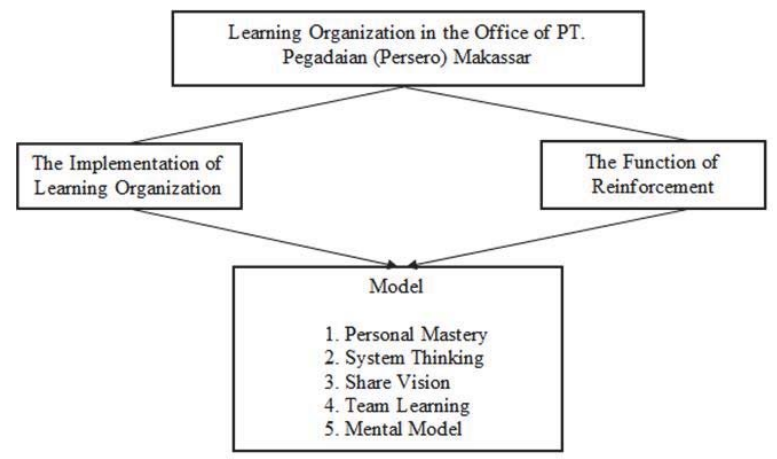

\section{Method}

This research was conducted at PT Pegdaian (Persero) in Makassar. This research described and analyzed the model of the learning organization with reinforcement approach. Based on the kinds of the research in which the researchers used a qualitative method, then this research examined a social phenomenon and human problems. In this study, a complex description is created by examining the words, a detailed report on the views of respondents. It is also conducted by studying on the natural situation (Creswell, 1998). This research produced descriptive data in the form of written and spoken by the people and behavior that are observed. This research used phenomenological approach. It is a way to collect data from individuals, in this case, the employees related to the assessment model of learning organization that is associated with reinforcement approach at the office of PT. Pegadaian (Persero) Makassar. In addition to informants' opinion, attitude or behavior of employees towards the provision of reinforcement can also be observed. Therefore, the described data were in the form of written and spoken words. The data were about the people and their behavior that were observed in the form of a sentence so that the data can be legitimate. Data were collected through interviews conducted structurally using interview guidelines. The guidelines are not rigidly implemented by researchers when they 
conducted this research because they are improved in accordance with the context and dynamics that develop when the study was conducted. In-depth interview was conducted with key informants from all categories of the research subjects. The key informants consisted of the employees of PT. Pegadaian (Persero), Makassar including a, ) regional chairperson, b) deputy chairperson, c) branch chairperson in the city of Makassar, c) chairperson of Assistant Branch Unit and some employees. The in-depth interview used a tape recorder to ensure that important information are disclosed by the informants. In addition, the researchers took pictures of the informants during the interview. Furthermore, the documentation studies were also conducted to encompass information that was presented in the form of documents such as written policies or rules related to the research problem. The documents consisted of a) the implementation of the learning organization management at PT. Pegadaian (Persero) Makassar, b) the Central Bureau of Statistics Makassar, c) historical documents of PT. Pegadaian (Persero), c) documents of learning organization at PT. Pegadaian (Persero) Makassar.

\section{Result and Discussion}

\subsection{Principles of Learning Organization}

Learning Organization based on some of the ideas and principles which integral into the organizational structure. Senge (2006: 21) in this case states that the core of the Learning Organization is Fifth Discipline (The Fifth Discipline). The fifth disciplines are five pillars underlying the research as a learning organization. It is said to have the characteristics of a learning organization if that is where the organization is continuously expanding the capacity of the knowledge of the five disciplines. The authors put forward one by one based on the priority need for training, namely Personal Mastery, System Thinking, Shared Vision, Learning Team and Mental Models; the fifth point is a point of continuous interrelated pillars as the discussion below:

1. Personal Mastery: Discipline that encourages an organization to continually learn how to create the future, which will only be formed if the individual members of the organization are willing and able to continue to learn to make himself a master in the field of science. The discipline of personal mastery is formed characterized by the growth of individual skills of the members of the organization contemplation (reflection) themselves; the skills to understand the strengths and weaknesses of intellectual competence, emotional and social herself; as well as the skills to do a revision of personal vision, and then the skills to build the working conditions in accordance with a state organization.

2. Systems Thinking: Discipline systemic thinking, the skills to understand the structure of the relationship between the various internal and external factors that affect the existence of the organization, the skills to think integrative and complete, the skills to think comprehensively, as well as the skills to build an organization that is adaptive, the discipline needed to build the discipline of systemic learning.

3. Building Shared Vision: Learning organization requires a shared vision, a vision that is agreed upon by all members of the organization. This shared vision will be a compass and simultaneously triggers passion and commitment to staying together, so the motivation for employees to learn and continue to learn to improve their competence. Skills to adjust the personal vision with the organization's vision, as well as the skills of shared vision in order to achieve personal goals contained in a shared vision of the organization, an individual discipline needed to build a shared vision discipline. That is, for a sense of commitment and high performance of all employees, should start from the shared vision.

4. Learning Team: The discipline of team learning can be effective if the members of the group have a mutual need for each other to act in accordance with a common plan. The ability to act is a prerequisite for creating the value-added organization, because, without a plan of action, it is just an illusion. The problem is the ability to act in accordance with a common plan often hampered simply because we are not able to communicate and coordinate properly with the other party. To that end, the spirit of dialogue, team collaboration skills, ability to learn and adapt, as well as efforts to increase participation, was the discipline needed to build the discipline of team learning.

5. Mental Models: Organizations will have difficulty to accurately able to see the different realities that exist, if the members of the organization are not able to formulate assumptions and values that are appropriate for use as a base way of thinking and way of looking at the problems of the organization. Discovering the principles and shared values skills and the growth of share value to foster the spirit of mutual confidence and commitment to strengthen the spirit of togetherness, are important disciplines to build a mental model of organizational discipline. 
Based on the fifth discipline above, it can be described as follows:

Firstly, Mastery Personal (Personal Mastery) is a personal expertise of individual employees who are able to control and fix the problem, someone who has the personal skills acquired through training in education will have a level of self-control are high and have the personal ability to take on the responsibility that is given and can carry out the task in a professional manner .For those people who have personal mastery then able to demonstrate the ability to clarify continually and deepen personal vision, focusing energies, developing patience, and see reality objectively. Personal mastery is also the learning activities to improve their personal capacities in order to create the best results we want, and create an organizational environment that encourages all its members to develop themselves towards the goals and objectives they choose later Personal mastery that had someone Good will always be positive in dealing with problems to create growth within organizations. Tjakraatmadja (2006: 153) confirms that personal mastery is the discipline that encourages an organization to continuously learn how to create the future, which will only be formed if the individual members of the organization are willing and able to continue to learn to make himself as a master in the field of study. Their knowledge they can improve emotional intelligence and gave birth a creative leadership.

Secondly, Thinking Systems (Systems Thinking) is a generative and conceptual way of thinking because both were able to see every occurrence of the phenomenon that rise to the surface, Systems Thinking is a way to analyze and think about the unity of the overall principles of the learning organization. People with systems thinking are usually able to think intelligently when confronted with a problem, people who have the ability to think the system is likely to make solutions Without the ability to analyze and integrate disciplines Learning Organization, may not be able to translate it into actiondiscipline discipline (activities) organization with more broad. People who think the system will be able to see the beneficial effects of the organization. This systems thinking helps us to see how we change systems more effectively and act more in tune with the processes that are larger than the natural and economic world. This system thinks understanding is almost the same as what was presented by Guthrie about Viewing organization as an integrated whole. According to Tjakraatmadja (2006: 155), the skills to understand the structure of the relationship between the various internal and external factors that affect the existence of its organization, the skills to think integrative and complete, the skills to think comprehensively, as well as the skills to build an organization that is adaptive, a discipline that is needed to build Systemic learn discipline (Systems Thinking).

Thirdly, Vision Shared (Building Shared Vision) is a vision that emerged from the personal vision that combine to form a common vision then becomes the root and the value held by the Organization in building together an ongoing basis to encourage its members to form a Share Vision to create strong synergies to organizational goals, a general description of the organization and the action (activity) organization that binds people together from the whole identification and feeling in question. With a shared vision of the organization can build a sense of commitment to a group, to create images together about the future being created, and the principles and practices guiding through which we expect to achieve the future. According to Tjakraatmadja (2006: 154), Shared Vision is a vision that is agreed upon by all members of the organization. This shared vision will be a compass and simultaneously triggers passion and commitment to staying together, in order to grow the motivation of employees to learn and continue to learn to improve their competence. Without a shared vision, the organizational learning process will only occur when an organization is in crisis. Once the crisis is over, they will again stop and go back to his old habits.

Fourthly, Learning Team is a process of learning in a team to achieve results in the set means a group of teams that learn together as a unity of mutual trust mutual respect and uphold the knowledge that co-exist and work together to achieve the goal, According to Peter Sang (1990) mentions that learning Team is fundamental learning in modern organizations if the team did not learn the organization was not learned. Learning organization will give birth to a conversation skills and expertise to think collectively with the same thinking of various complex issues faced by the organization, so that groups of people can be reliable and able to develop intelligence and ability greater than the amount of talent of its members. According Tjakraatmadja (2006: 155), the discipline of team learning (learning team) will be effective if the members of the organization have a mutual need between one another to be able to act in accordance with a common plan. Dialogue (Dialogue Generatively) is a fundamental part of the learning in team or Learning Organization. In the simplest sense, the dialogue is communication. It is a combination of various interactions within the organization. Through dialogue, individuals with interactive digging and completing one or all aspects of the action in the organization, how they accept the system and the structure of the organization, what their organizational vision. Dialogue is an important part of the Learning Organization. Only with dialogue, individuals can explore the interactive various issues that exist in the organization. An important point of dialogue is not only to understand what is happening in the organization, how individuals get to experience the structure and processes within the organization, but also to direct the new models, new openness, and new goals to get more effective action and understanding and confidence depth

Fifthly, Models of Mental (Mental Models) is an activity of reflection that continually clarify and improve internal 
picture of the scope of the organization and see how to shape the actions and decisions within the organization, or in other words, mental models related to how a person thinks deeply about why and how to perform actions or activities in the organization. The fundamental principles of Mental Models, with the learning organization in it are allowed to think and reflect on the structure and direction (command) in the organization and also from the outside world other than the organization. Senge (2006) states that mental models to see how to approach problems. In other words, mental models can be regarded as a concept of a person, which is the self-concept that he will take the best decision. Tjakratmadja (2006: 154) adds that the skills to discover the principles and shared values, as well as the growth of share value to foster the spirit of mutual confidence and commitment to strengthen the spirit of togetherness, a discipline that is needed to build a mental model of organizational discipline.

\subsection{Implementation of Learning Organization in PT Pegadaian}

PT. Pegadaian (Persero), Makassar, has implemented the five disciplines that make up the learning organization as proposed by Senge, namely personal mastery,, system thinking, shared vision, and mental Learning Team model. The fifth discipline is implemented fairly well at the office of PT Pegadaian (Persero) Makassar, judging from interviews and observations of employees below, that each employee trying to find innovative solutions to get the job done because the ability of personal mastery that have made every employee will be encouraged to improve the workability; employees who have thought the system would be willing to accept criticism and suggestions; because the success of an employee in a unit of work is strongly influenced by other work units, whereas the share of vision is a common vision to address future is uncertain because the condition of the times continues to grow, at learning team every employee stated desire to learn to develop ideas and increase competence so that they have the knowledge and know-how to increase and broaden. The employees of PT Pegadaian (Persero) Makassar who have a mental model in terms of characteristics and skills show good results. It can be seen from every employee has any desire or belief that the work program at the company PT Pegadaian (Persero) Makassar can be implemented properly, and result ideals are one motif someone who has a high competence; each employee will continue to make creative innovations improve performance; each employee will maximize customer satisfaction/customer within the organization with knowledge.

The employees of PT Pegadaian (Persero) Makassar still have a lack of knowledge on learning organizations and tend to be passive. They do not want to be bothered by running self-improvement efforts are very burdensome. They assume that learning is no more than a restraint and cut the values of freedom. But unfortunately, these reasons unconsciously in understanding the learning will be contained value the freedom to work and creativity. Thus, employees who are in this group is satisfied and does not want to interfere again from the comfort zone atmosphere that is enjoyed. They have a purpose in life unknown direction and may also not have the vision to run a good life for personal and corporate. They are also very heavy in adjusting to developments and changes in the environment at the time of the growing conditions.

Application of reinforcement on Learning Organization Model at PT Pegadaian (Persero) Makassar is an approach so that employees can follow learning well, and in general has been applied by the respective leaders of both branches and unit offices in Makassar. It is due to existence creativity leaders to develop learning materials or materials independently, the background of the application of Reinforcement Learning at PT Pegadaian (Persero) Makassar using maximum preparation by the leadership at the time to be a discussion or dialogue, in sharing knowledge of Learning Organization,, flexibility to apply all components of teaching skills and the active participation of employees will imitate the learning from the experience of fellow Leaders in teaching. All people are contributing to providing motivation or encouragement in its application. Reinforcement applied in the implementation of the Pegadaian branch office in Makassar need skills of leadership which provides verbal reinforcement in the form of words at the branch office of PT.Pegadaian or at unit offices in Makassar has been uneven and conducted in accordance with the theory reinforcement that in giving verbal reinforcement in the form of praise words against employees of PT Pegadaian Makassar are often accompanied by the strengthening of the non-verbal. While the leadership skills provide verbal reinforcement in the form of a sentence on the employees of PT Pegadaian both on learning and on the implementation of the work looks quite serious use in the implementation of learning. While the leadership skills provide reinforcement in the form of strengthening the non-verbal expression on the face, or the strengthening of the approaching employees with a touch, or reinforcement in the form of gifts is already done by teachers well. But not all of the Branch Managers evenly use non-verbal skills. In the fifth case of reinforcement, non-verbal skills provide reinforcement in the form of reinforcement with a fun activity turns more often providing the leadership and use them in the implementation of learning. Or in general, has been done by the leaders of the Branch but it is still very limited.

Reinforcement that is used still seems less varied or diverse, and still not fully optimality is due to limited facilities 
and infrastructure as a support in learning that results in slow learning activities itself. Then, in explaining or describing discussions materials, there are still some carrier materials that use e monotonous methods, within the meaning of the discussions in the practice of professional skills is still minimal and less unfair leadership rewards or attention to employees and also due to the lack of creativity of employees was alone. In providing reinforcement, strengthening the leadership can provide a form of verbal reinforcement and non-verbal learning which will effectively be able to avoid feeling bored and tired for employees who participate the learning, so that the learning will be effective, creative and pleasant and the learning objectives will be easily reached. Besides strengthening the leadership of learning was also used to intersperse with little humor or funny stories just to normalize the learning activity. Reinforcement gives contribution for creativity and improvement of productive behavior of employees will be able to increase the employee's attention towards learning. There is sometimes declining of attention to learning that is caused by time in the learning process that creates boredom. These skills will remove the boredom to the increase the attention given to the learner's employees, to stimulate and improve their motivation.

\section{Conclusion}

Learning Organization Model (learning organization) in PT Pegadaian (Persero) Makasar has been running long as an example in the field of Personal Mastery or personal expertise to provide education or course hierarchy starting from (1) Training leader of young (2), the course for leaders to (3) courses for major leaders with the third learning models in the field of personal mastery is the requirement to hold a position so that the personal skill is really needed because it can create development of personal skills mastery of character and commitment and high responsibility. To make the learning model in the field of Systems thinking referring to personal Mastery learning to improve thinking ability system so the employees are able to see the beneficial effects for the company with the ability to control the problem, learning model which has been followed in personal Mastery will give birth to systems thinking systems are effective to face problems so they can make decisions quickly because the thinking system trains us not to give up and is responsible for should be done and be more willing to take a decision, learning model at the stage of thinking system includes three phases: the first is the systems thinking forms the problem and gather all data, the second stage of the systems thinking distract from to the problems faced and the third stage evaluates toward solving the third problem that stage gave birth to the training model to Share Vision which include, (1) Training Association, (2) training management of branch (3) training managerial level. The third is shared vision learning models can build on the vision of a shared vision because PT. Pegadaian office can develop ideas that play a role in the organization for the company, then the learning team model aimed on how a team with the same thinking can face complex problems with learning organization and how to create effective thinking, learning models on the systems thinking includes (1) the discussion (2) Dialogue) (3) Sharing of knowledge then the learning model on the fifth discipline is the mental model that the forms big ideas that sharpen great thought, it is expected to grow in an organization with humble personal discipline besides mental model is needed in the field of organizational learning, mental learning models include the creation of a model of mental discipline, personal humble, flexible, Polite, Tolerance, and humorist. While in the reinforcement on the application of learning Organization, the leaders should be able to apply the principles and strengthening accordance with the manner appropriate to the reinforcement components, varied so that the employee is not saturated, and in accordance with the development of the employees that are well motivated; The next leader should be able to generate interest in learning employees to employees interested in learning material to improve learning outcomes and work well.

Thus, Learning Organization is necessary to develop and improve sustainable performance in institution education providers. It can be achieved if the education provider at Pegadaian office in Makasar implemented with a consistent and disciplined by five principles, namely Learning Organization, Personal mastery, Thinking system, a shared vision, Learning Team and Mental Models.

\section{References}

Argyris, C. (2008). On Organizational Learning. (2nd Ed). Oxford: Blackwell Publishing.

Argyris, C., \& Schön, D. (2008). Organizational learning: A theory of action perspective, Reading. Boston: Addison Wesley.

Dewi, Evita. (2009). Motivasi, Drive Reinforcement, Teori Harapan. Retrieved from: http://evitadewiblogqu.blogspot.com/2009/11/ motivasi-drive-reinforcement-teori.html (accessed on 20 September 2015).

Gephart. (2006). Learning Organization. Boston: Harvard Business School Press.

Haryanti. (2006). Learner Organization. Jakarta: Rineka Cipta.

Kreitner. (2006). Leadership for Improving Productivity of Schools. New York: John Willey \& Sons Inc.

Marquardt, M., \& Reynolds, A. (2003). The Global Learning Organization. Illinois: Irwin Professional Publishing. 
Marquardt, Michael J. (2002). Building a Global Learning Organization in Understanding Learning Organizations. La Hulpe: ECLO Press. Marquardt, Michael J. (2006). Building the Learning Organization a Systematic Approach to Quantum Improvement and Global Success. New York: McGrow-Hill.

Mayo, A., \& Lank, E. (1994). The Power of Learning. A Guide to Gaining Competitive Advantage. London: IPD House.

Mondy, R. Wayn. (2012). Study Guide for Human Resource Management. Cram Textbook Reviews.

Pedler, M., Burgogyne, J., \& Boydell, T. (2005). The Learning Company: A Strategy for sustainable development. London; McGraw-Hill.

Schwandt, David R., \& Marquardt, Michael J. (2000). Organizational Learning. Boca Raton: St.Lucie Press.

Senge, Peter M. (2006). The Fifth Discipline, The Art \& Practice of the Learning Organization. New York: Doubleday Dell Publishing Group.

Senge, P., Cambron-McCabe, N. Lucas, T., Smith, B., Dutton, J., \& Kleiner, A. (2006). Schools That Learn. A Fifth Discipline Fieldbook for Educators, Parents, and Everyone Who Cares About Education. New York: Doubleday/Currency.

Senge, P., Kleiner, A., Roberts, C., Ross, R., Roth, G.\& Smith, B. (2006). The Dance of Change: The Challenges of Sustaining Momentum in Learning Organizations. New York: Doubleday/Currency).

Senge, Peter M., Kleiner, Art., Roberts, Charlotte, Ross Richard B., Smith, Bryan J. (2006). The Fifth Discipline Field book. New York: Currency Doubleday.

Senge, Peter. (2006). Schools That Learn: A Fifth Discipline Fieldbook for Educators, Parents, and Everyone who cares about Education. USA: Nelda Cambron-McCabe.

Senge, Peter., Kleiner, Art., Ross, Richard., Roth, George., \& Smith, Bryan. (2006). The Dance of Change. New York: Currency Doubleday.

Toyibin. (2010). Reinforcement in Teaching and Learning Activities. Retrieved from: http://paktoyibin.blogspot.com/2010/04/rein forcement.html_(accessed on 20 September 2015).

Tjakraatmadja. (2006). Technic of Design. Bandung: ITB Bandung. 